\title{
ANALYSIS ON THE SOCIETY INDICATOR OF CORPORATE SOCIAL RESPONSIBILITY (CSR) OF PT ANTAM
}

\author{
Nuraini Sari; Michael Wijaya \\ Accounting and Finance Department, Faculty of Economic and Communication, BINUS University \\ Jln. K. H. Syahdan No. 9, Palmerah, Jakarta Barat 11480 \\ sari.nuraini@gmail.com; mhadipoespito@binus.edu
}

\begin{abstract}
Stakeholders believe that CSR report of a company provides significant information as well as the financial information reported in financial statement. The purpose of this research is to analyze the comprehensiveness and information on society indicator stated in the Corporate Social Responsibility (CSR) reporting. The Global Reporting Initiative's (GRI) Sustainability Reporting Guidelines (version 3.1) provides indicators to analyze the CSR of company. This research focuses on society aspect as one of the performance indicators. Comprehensive reporting contains three types of information: (i) vision and goals, (ii) management approach, and (iii) performance indicator. The methodology used in this research was data collection. This research analyzed the disclosure of society aspect by PT Antam on their financial statement and annual CSR report for the year 2012. The result of this research explains that PT Antam's sustainability report for the year 2012 was comprehensive because they reported all the six aspects of society indicator. However, PT Antam failed to report the total value of financial and in kind contributions to political parties, politicians, and related institutions by country (SO6) as part of public policy aspect in their sustainability report.
\end{abstract}

Keywords: Corporate Social Responsibility (CSR), Global Reporting Initiative (GRI), financial statement, performance indicator, society aspect

\begin{abstract}
ABSTRAK
Stakeholder memercayai bahwa laporan CSR perusahaan memberikan informasi penting serta informasi keuangan yang dilaporkan dalam laporan keuangan. Tujuan penelitian ini adalah untuk menganalisis kelengkapan dan informasi pada indikator masyarakat yang dinyatakan dalam pelaporan Corporate Social Responsibility (CSR). Pedoman Pelaporan Keberlanjutan Global Reporting Initiative (GRI) (versi 3.1) menyajikan indikator untuk menganalisis CSR perusahaan. Penelitian memfokuskan pada aspek masyarakat sebagai salah satu indikator kinerja. Pelaporan yang komprehensif berisi tiga jenis informasi: (i) visi dan tujuan, (ii) pendekatan manajemen, dan (iii) indikator kinerja. Metodologi yang digunakan dalam penelitian ini adalah pengumpulan data. Penelitian menganalisis pengungkapan aspek masyarakat oleh PT Antam pada laporan keuangan dan laporan tahunan CSR untuk tahun 2012. Hasil penelitian menjelaskan bahwa laporan keberlanjutan PT Antam untuk tahun 2012 adalah komprehensif karena mereka melaporkan semua enam aspek indikator masyarakat. Namun demikian, PT Antam tidak melaporkan nilai total finansial dan kontribusi natura kepada partai politik, politisi, dan institusi terkait menurut Negara (SO6) sebagai bagian dari aspek kebijakan publik dalam laporan keberlanjutan mereka.
\end{abstract}

Kata kunci: Corporate Social Responsibility (CSR), Global Reporting Initiative (GRI), laporan keuangan, indikator kinerja, aspek masyarakat 


\title{
INTRODUCTION
}

Companies are established to pursue profit mainly by selling their products or services. Every now and then, company abuses their sources, ignores the society and environment, or breaking the law so they can achieve their goals which is primary to maximize its profit. Other strategies to maximize company's profit or to expand the market are through merger, business combinations, or collusion which involving price rigging and business manipulation. However, at one point, companies and their stakeholders realized that such as actions will only provide a short-term profit. There is another factor that can give a contribution to improve the company's strategy and profit.

Corporate Social Responsibility is not a new concept. Corporate Social Responsibility (CSR) is a concept that has changed worldwide perspective. In the past, financial statement becomes the only information needed by the stakeholders to make a decision on their investment. Nowadays, stakeholders believe that the aspect of social and environmental accountability also provides information regarding the values, objectives and quantified targets of a company. CSR addressing not only economic factor, but the balance between economic, social and environment impact to help company to improve business strategies, achieve a long-term profit and building shareholders value. Therefore, nowadays companies provide the information about their economic condition (reported on their financial statements) and social-environment sustainability (reported on their CSR report).

However, the previous studies have revealed that it is highly doubtful that current CSR reporting provides a fair view of a company's CSR performance to the stakeholders. This doubt mainly originates from the fact that the companies predominantly provide narrative CSR information, which usually was tailored to manage public impression (Adams et. al., 1995; Neu, Warsame, and Pedwell, 1998). Comprehensive reporting requires three information types to be provided for each disclosed CSR item: (i) vision and goals (VG); (ii) management approach (MA); and performance indicator (PI) (L. Bouten et al., 2011). The comprehensiveness of CSR reporting can be captured not only by (i) the disclosed CSR items but also (ii) the accompanying information types (VG, MA, and PI) (L. Bouten et al., 2011).

There are six areas of performance indicator based on Global Reporting Initiative (GRI) that should be the focus on analyzing the comprehensiveness of CSR: (1) Economic, (2) Environment, (3) Human rights, (4) Labor practice and decent work, (5) Product responsibility, (6) Society. However, this research will be focused on Society indicator. The concept of CSR is relatively new among the companies in Indonesia. CSR implementation in Indonesia is mandatory for a company with limited liability. Under Law No. 40/2007, section 74, it states:

\begin{abstract}
"(1) Companies doing business in the field of and/or in relation to natural resources must put into practice Environmental and Social Responsibility. (2) The Environmental and Social Responsibility contemplated in paragraph (1) constitutes an obligation of the Company which shall be budgeted for and calculated as the cost of company performance of which shall be with due attention to decency and fairness. (3) Companies who do not put their obligation into practice as contemplated in paragraph (1) shall be liable to sanction in accordance with the provision of legislative regulations. (4) Further provisions regarding Environmental and Social Responsibility shall be stipulated by Government Regulation."
\end{abstract}

PT Antam is a diversified mining company and vertically integrated, export-oriented. Their operations are spread across Indonesia. PT Antam activities include exploration, mining, processing and marketing of nickel ore, feronike, gold, silver, bauxite and coal. PT Antam is a listed company. As a mining company, PT Antam realizes that the company's operations have a direct impact on the environment and surrounding communities. The company recognizes that aspects of the environment 
and development of social responsibility is not just a part of the company's risk but must be also managed properly.

PT Antam is using the GRI G3.1 which is the latest version of the Standard Disclosure of CSR. In addition, PT Antam also use the framework of Mining and Metals Sector Supplement (MMSs) issued by GRI. Therefore, this research will analyze the disclosure of society aspect by PT Antam in their financial statement and annual CSR report for the year 2012 to see whether PT Antam has been disclosed all the society indicators stated in the GRI G3.1.

\section{RESEARCH METHOD}

This paper aims to illustrate the application of the framework by analyzing the disclosures of PT Antam's CSR report. Although the framework can be used to analyze all types of written texts (such as websites and stand-alone reports), in line with the majority of previous studies (Beck et al., 2010), PT Antam's 2012 financial reports and annual reports were used as the basis of analysis. The financial report and annual report play an important role in the accountability-discharge activity of companies because they are widely distributed and often directly available on the company's website and because they are considered as the most important tools used by companies to communicate with their stakeholders (Neu et al., 1998). In addition, stakeholder studies (O’Dwyer, Unerman, \& Hession, 2005) indicate that the annual report is a widely favored information source. This paper will only analyze the disclosure of society aspect by PT Antam in their financial statement and annual CSR report for the year 2012 .

To assess the level of comprehensive reporting, a content analysis framework was developed. Content analysis can be defined as a method of codifying text into different groups depending on selected criteria (Weber, 1990). This method has been frequently used to understand and describe the patterns in CSR reporting (Guthrie \& Abeysekera, 2006).

\section{Coding Structure}

The coding structure consists of two dimensions: (i) content and (ii) information types. The first dimension consists of two levels: (i) areas and (ii) items. The coding structure has the form of a coding tree. The coder first decides on the area of disclosure, then on the item of disclosure and finally on the information type. Following Krippendorff (2004), a coding structure in the form of a decision tree has the following advantages: (i) criteria confusion is minimized, (ii) decision schemes can drastically reduce large numbers of alternatives, (iii) decision schemes can prevent unreliability due to categories being defined on different levels of generality or that overlap in meaning and (iv) when recording involves several dimensions of judgment, decision schemes offer coders the opportunity to determine each one separately.

\section{Content: GRI as Reference}

Although no consensus exists on what CSR reporting means (Guthrie et al., 2008), appropriate content analysis demands that the coding structure is derived from shared meanings (Beattie \& Thomson, 2007). Therefore, the Global Reporting Initiative's (GRI) Sustainability Reporting Guidelines (version 3.1) served as an appropriate starting point for the development of the coding structure because the GRI framework is global, has international acceptance (Farneti \& Guthrie, 2009), is considered a rigorous framework for the application of triple bottom line reporting (Lamberton, 2005) and was drafted by a wide variety of experts after stakeholder consultation (Reynolds \& Yuthas, 2008). Furthermore, the GRI guidelines are readily available on the GRI's website. These guidelines are intended for all types of companies, allowing for the derived coding 
structure to be used for different industries (Willis, 2003). Although the GRI has developed sector supplements for a few industries, the GRI still considers these guidelines to be the cornerstone of the GRI Sustainability Reporting Structure. These guidelines outline the core content for reporting and are relevant to all organizations, regardless of their size, sector or location. They form the foundation upon which all other GRI reporting guidance is based (www.globalreporting.org). Finally, the GRI guidelines provide a structured overview of the base content of CSR reporting. The base content is divided into six areas (economic, environment, human rights, labor practices and decent work, product responsibility, and society) and several items. This approach adds directly to the transparency and replicability of the content analysis because other researchers can also use these guidelines to determine which area and item a disclosure belongs to.

\section{Information Type}

The GRI suggests that a company should provide different information types (strategy and profile, management approach and performance indicators) when it discloses a CSR item. However, these categories are not clearly defined. Therefore, the second dimension distinguishes between three information types, based on the work of Vuontisjärvi (2006): (i) Vision and goals (VG), in line with Vuontisjärvi (2006), this category includes disclosures that provide information on stated aims or values. This category thus covers corporate recognition of the values of CSR (e.g., striving for a reduction in energy consumption. (ii) Management approach (MA), similar to Vuontisjärvi (2006), this category covers how the company addresses a given CSR issue by describing the action or practice adopted, and it corresponds to the second level, 'Specific Endeavour', of Robertson and Nicholson's (1996) hierarchy. (iii) Performance indicators (PI), similar to Vuontisjärvi (2006), this category reflects actual CSR achievements by providing quantitative measures of CSR performance.

\section{Instrument Reliability}

Bouten followed the approach suggested by Krippendorff (2004) to ensure that the definitions of the content analysis categories were reliable. Before the coding structure was used, it was tested to determine whether the definitions of the different categories were workable. This process involved three test coders working independently. The coding structure and the initial coding rules, based on the GRI guidelines, were tested by using them to identify and record the CSR disclosures in five annual reports. Afterwards, the results were discussed and compared. Following this step, the coding structure was modified slightly, and the decision rules refined. The process was then repeated with five new reports until all three test coders agreed (after two rounds). Adjustments to the coding structure were made (i) to further comparability with other social and environmental content analysis studies, (ii) to be sure that each frequently reported item was included in the content analysis framework and (iii) to obtain well-specified areas and items with well-specified decision rules.

\section{Coding Reliability}

Coding reliability means that the coded data produced by the content analysis are, in fact, reliable. To ensure coding reliability, all reports were coded by three persons. Coding discrepancies between coders were re-analyzed, discussed and reconciled (Milne \& Adler, 1999).

\section{Identifying and Quantifying CSR Disclosures}

Before verifying the presence of an item and the disclosure type, it was necessary to read each report to identify and code every sentence that contained CSR information by assigning a content and information type label to it. In line with most social and environmental content analyses, the sentence was thus used as the unit of analysis (Guthrie et al., 2008). 


\section{Level of Comprehensive CSR Reporting}

The main contribution of the content analysis framework is that it assesses the comprehensiveness of CSR reporting by verifying whether a company releases information on VG, MA and PI concerning a specific CSR item. Based on this information, a measure for the level of comprehensive CSR reporting can be constructed as follows:

Level of comprehensive reporting = number of items for which all 3 information types (VG, MA, PI) are disclosed number of items reported by the company

The level of comprehensive reporting reveals the extent to which a company discloses all three information types for the items they report on.

\begin{tabular}{|c|c|}
\hline Areas & Items \\
\hline Society & $\begin{array}{ll}\text { 1. } & \text { Local Communities } \\
\text { 2. } & \text { Corruption } \\
\text { 3. } & \text { Public policy } \\
\text { 4. } & \text { Anti-competitive behavior } \\
\text { 5. } & \text { Compliance }\end{array}$ \\
\hline
\end{tabular}

Figure 1 The GRI as Reference for the Dimension Content

Table 1 The Aspects and Components of Society Indicator

\begin{tabular}{|c|c|c|}
\hline Aspect & Code & Component \\
\hline \multirow[t]{5}{*}{ Local Communities } & SO1 & $\begin{array}{l}\text { Percentage of operations with implemented local } \\
\text { community engagement, impact assessments, and } \\
\text { development programs }\end{array}$ \\
\hline & $\begin{array}{l}\text { MM6 (Mining and Metals } \\
\text { Sector-Specific Commentary } \\
\text { on MM6 Indicator Protocol) }\end{array}$ & $\begin{array}{l}\text { Number and description of significant disputes } \\
\text { relating to land use, customary rights of local } \\
\text { communities and indigenous peoples }\end{array}$ \\
\hline & $\begin{array}{l}\text { MM7 (Mining and Metals } \\
\text { Sector-Specific Commentary } \\
\text { on MM7 Indicator Protocol) }\end{array}$ & $\begin{array}{l}\text { The extent to which grievance mechanisms were } \\
\text { used to resolved disputes relating to land use, } \\
\text { customary rights of local communities and } \\
\text { indigenous peoples and the outcomes }\end{array}$ \\
\hline & SO9 & $\begin{array}{l}\text { Operations with significant potential or actual } \\
\text { negative impacts on local communities }\end{array}$ \\
\hline & SO10 & $\begin{array}{l}\text { Prevention and mitigation measures implemented } \\
\text { in operations with significant potential or actual } \\
\text { negative impacts on local communities }\end{array}$ \\
\hline \multirow[t]{3}{*}{ Corruption } & $\mathrm{SO} 2$ & $\begin{array}{l}\text { Percentage and total number of business units } \\
\text { analyzed for risks related to corruption }\end{array}$ \\
\hline & SO3 & $\begin{array}{l}\text { Percentage of employees trained in organization's } \\
\text { anti-corruption policies and procedures }\end{array}$ \\
\hline & $\mathrm{SO} 4$ & $\begin{array}{l}\text { Actions taken in response to incidents of } \\
\text { corruption }\end{array}$ \\
\hline \multirow[t]{2}{*}{ Public Policy } & SO5 & $\begin{array}{l}\text { Public policy positions and participation in public } \\
\text { policy development and lobbying }\end{array}$ \\
\hline & SO6 & $\begin{array}{l}\text { Total value of financial and in kind contributions } \\
\text { to political parties, politicians, and related } \\
\text { institutions by country }\end{array}$ \\
\hline $\begin{array}{l}\text { Anti-competitive } \\
\text { Behaviour }\end{array}$ & SO7 & $\begin{array}{l}\text { Total number of legal actions for anti-competitive } \\
\text { behavior, anti-trust, and monopoly practices and } \\
\text { their outcomes }\end{array}$ \\
\hline
\end{tabular}




\begin{tabular}{lll}
\hline Compliance & SO8 & $\begin{array}{l}\text { Monetary value of significant fines and total } \\
\text { number of non-monetary sanctions for non- } \\
\text { compliance with laws and regulations }\end{array}$ \\
\hline & $\begin{array}{l}\text { Mining and Metals Sector- } \\
\text { Specific Commentary on SO8 } \\
\text { Indicator Protocol: }\end{array}$ & $\begin{array}{l}\text { Commentary added on judgments related to } \\
\text { health, safety and labor laws }\end{array}$ \\
\hline
\end{tabular}

\section{RESULTS AND DISCUSSION}

PT Antam has vision and mission regarding the CSR and as based of PT Antam's CSR Masterplan. CSR vision of PT Antam is to become a leading and most-trusted company with social responsibility in Indonesia's mining industry. While CSR mission of PT Antam are (1) to implement excellent CSR in accordance with international standards, (2) to implement the best CSR program among national mining companies, (3) and to implement highly credible CSR programs with high benefit for all stakeholders. While the management approach is based on mapping and stakeholders' engagement plans on PT Antam's sustainability report for the year 2011. The results of mapping and stakeholder engagement plans were carried out throughout 2012, and will continue to be implemented in the future, until the map and plans are revised.

PT Antam continues to carry out the business and operational activities by upholding the principles of sustainability including manifesting them in PT Antam CSR Masterplan. The Masterplan implementation is focused on social development performance and is directly monitored by the General Affairs and CSR Directorate. This research is comparing all components of Society indicator that should be stated in CSR report based on GRI with the components on PT Antam's CSR report to analyze the compliance and comprehensiveness of PT Antam sustainability report. Components of Society indicator stated on PT Antam's sustainability report for the year 2012 are as follows.

SO1: the development of social facilities were part of PT Antam's implementation of good mining practice principles, as well as a commitment to create a sustainably beneficial post-mining area, in terms of social, economics, ecological, and aesthetics for surrounding communities. The sustainability strategy is implemented by building relationships with the community to establish a good relationship and recognize the local social cultural characteristics. The activities include: (1) dissemination to community figures and relevant government officials, (2) preparation of Analysis on Environmental Impact (Amdal) on the mine site, [MM2] (3) preparation of Mine Closure Plan (RPT) on the mine site. PT Antam has organized various programs and activities aimed at empowerment and development of community around the operations and post-mining sites of the Company. The programs and activities have been carried out since PT Antam conducts dissemination until operation termination or post-mining. During 2012, PT Antam also continued and completed several programs and activities to improve the welfare of the community in the post-mining area.

SO2 and SO4: PT Antam has an internal control review (ICR) system in their business units and Head Office. The system is implemented by the Internal Audit Division. The result in 2012 was good in average. In 2012, there was one report of whistle blowing submitted. Currently, the report has been monitored by the Directors and the Board of Commissioners. The investigation is still in progress and will be completed referring to the Articles of Association and other legal provisions.

SO3: PT Antam continually enhances the Board of Directors and employees' understanding on anti-corruption issues. This was done by including anti-corruption material in various briefings and dissemination. PT Antam includes the anti-corruption material on their Leadership Development 
Program training, both at the Basic Leadership Development Program (BLDP), Middle Leadership Development Program (MLDP) and Senior Leadership Development Program (SLDP).

SO5: PT Antam active in participates in forums involving authorities, including those related to public policy. One of these activities was a hearing with Commission VII of the House of Representatives in March 2012. This hearing session discussed the application of export ban on ores or minerals in raw form. PT Antam is also supporting the development planning forum (musrenbang) held by each local government where the Company's operations area located. Through musrenbang, PT Antam discusses various development programs with local government, particularly in relation to the needs of local communities.

SO7 and SO8: PT Antam supports fair competition in the industry. The Company has never engaged in price fixing practices that can directly control product selling price. The selling price of product is subject to foreign commodity exchanges such as London Bullion Market Association (LBMA) for gold products, and London Metal Exchange (LME) for other processed mineral products. PT Antam has always complied with the regulations on these products sales and thus never faced allegation on business competition violation.

SO9 and SO10: PT Antam's CSR Masterplan covers all stages of activities that may have potential positive and negative impact including exploration, construction, operation up to mine closure and post-mining activities. The Masterplan is expected to meet the stakeholders' needs according to the Company's ability, including respect for the community's rights, acknowledging the community's characteristics to interact, recognize the 'work value' in partnership and social investment to add value for the community. Thus, the Masterplan can be an alternative form of control over the potential negative impacts.

\section{CONCLUSION}

Comprehensive reporting requires three information types to be provided for each disclosed CSR item: (i) vision and goals (VG); (ii) management approach (MA); and performance indicator (PI). PT Antam provided the vision, goals and management approach on their sustainability report. There are six areas of performance indicator based on Global Reporting Initiative (GRI) that should be the focus on analyzing the comprehensiveness of CSR. One of the indicators is society. There are five aspects that should be stated in the CSR report based on Global Reporting Initiative (GRI). PT Antam reported all the six aspects. However, PT Antam failed to report the total value of financial and in kind contributions to political parties, politicians, and related institutions by country (SO6) as part of public policy aspect in their sustainability report.

\section{REFERENCES}

Adams, C. A., Hill, W. Y., and Roberts, C. B. (1995). Environmental, Employee and Ethical Reporting in Europe. London: ACCA Research Report, No. 41.

Beattie, V., and Thomson, S. J. (2007). Lifting the lid on the use of content analysis to investigate intellectual capital disclosures. Accounting Forum, 31(2), 129-163. 
Beck, A. C., Campbell, D., and Shrives, P. J. (2010). Content analysis in environmental reporting research: Enrichment and rehearsal of the method in a British-German context. British Accounting Review, 42(3), 207-222.

Farneti, F., and Guthrie, J. (2009). Sustainability reporting by Australian public sector organisations: Why they report. Accounting Forum, 33(2), 89-98.

Guthrie, J., \& Abeysekera, I. (2006). Content analysis of social, environmental reporting: What is new? Journal of Human Resource Costing and Accounting, 10(2), 114-126.

Guthrie, J., Cuganesan, S., \& Ward, L. (2008). Industry specific social and environmental reporting: The Australian food and beverage industry. Accounting Forum, 32(1), 1-15.

Krippendorff, K. (2004). Content Analysis: An Introduction to Its Methodology. Thousand Oaks, California: Sage Publications.

Lamberton, G. (2005). Sustainability accounting-A brief history and conceptual framework. Accounting Forum, 29(1), 7-26.

Milne, M. J., and Adler, R. W. (1999). Exploring the reliability of social and environmental disclosures content analysis. Accounting, Auditing \& Accountability Journal, 12(2), 237-256.

Neu, D., Warsame, H., and Pedwell, K. (1998). Managing public impressions: Environmental disclosures in annual reports. Accounting, Organizations and Society, 23(3), 265-282.

O’Dwyer, B., \& Owen, D. L. (2005). Assurance statement practice in environmental, social and sustainability reporting: A critical evaluation. British Accounting Review, 37(2), 205-229.

PT Antam. (2012). Laporan Keberlanjutan Perusahaan Persero PT Aneka Tambang.

Reynolds, M. A., and Yuthas, K. (2008). Moral discourse and corporate social responsibility reporting. Journal of Business Ethics, 78(1-2), 47-64.

Vuontisjärvi, T. (2006). Corporate social reporting in the European context and human resource disclosures: An analysis of Finnish companies. Journal of Business Ethics, 69(4), 331-354.

Weber, R. P. (1990). Basic content analysis (2nd ed.). Sage University Paper Series on Quantitative Applications in the Social Sciences, Series No. 49. Newbury Park, CA: Sage.

Willis, A. (2003). The role of the Global Reporting Initiative's sustainability reporting guidelines in the social screening of investments. Journal of Business Ethics, 43(3), 233-237. 